\title{
Katastrofik Sağlık Harcamaları Anket Çalışması: Örneklem Seçimi ve Veri Toplama Yöntemi
}

\section{Bekir Burçay ERUS ${ }^{1}$}

\begin{tabular}{l} 
ARTICLE INFO \\
\hline Article History: \\
Date Submitted: 08.06 .2017 \\
Date Accepted: 01.08.2017 \\
\hline JEL Classification: \\
I14 \\
I31 \\
I32
\end{tabular}

Keywords:

Catastropic

Health Expenditure

\begin{abstract}
Katastrofik sağlık harcamaları ödeme kapasitesinin \%40'ından yüksek sağlık harcaması olarak tanımlandığında, söz konusu harcamaları yapan ailelerin oranının gerek TUİK gerekse diğer çalışmalar tarafından \%1'in altında hesaplandığını belirten Erus, tanım değiştirildiğinde dahi söz konusu oranın \% $\%$ 'e nadiren ulaştığının altını çizmiştir. "Sağlık harcamaları nedeniyle aile bütçeniz sarsıldı mı" (2013 yılında Şahin vd.) şeklindeki öznel bir soruya \%26'lık bir olumlu cevap verildiğini ancak bunun öznel bir bakış açısı içerdiğini belirtmiştir. $\mathrm{Bu}$ nadir durumun bileşenleri, nedenleri ve ona maruz kalanların kim olduklarını açığa çıkartma amacında olduklarını ve nadir görülen durumların anket yoluyla incelenmesinde başlıca sorunun anlamlı bir örnekleme ulaşabilmek için çok yüksek sayıda haneye anket yapmak zorunluluğu olduğunu vurgulamıştır. \%5 oranında bir katastrofi tespit edebilmek için çok kaba bir hesapla 20.000 anket yapılması, \%1 katastrofi için, yine kaba bir hesapla, 100,000 örneklem gerekliliği örnekleri ile durumun güçlüğünü net bir şekilde ortaya koymuştur.
\end{abstract}

\footnotetext{
${ }^{1}$ Boğaziçi Üniversitesi, İktisadi ve İdari Bilimler Fakültesi, Ekonomi Bölümü Öğretim Üyesi, burcay.erus@boun.edu.tr
} 
Katastrofik sağlık harcamaları ödeme kapasitesinin \%40'ından yüksek sağlık harcaması olarak tanımlandığında, söz konusu harcamaları yapan ailelerin oranının gerek TUİK gerekse diğer çalışmalar tarafından \%1'in altında hesaplandığını belirten Erus, tanım değiştirildiğinde dahi söz konusu oranın \%5'e nadiren ulaştığının altını çizmiştir. "Sağlık harcamaları nedeniyle aile bütçeniz sarsıldı mı" (2013 yılında Şahin vd.) ş̧eklindeki öznel bir soruya \%26'lık bir olumlu cevap verildiğini ancak bunun öznel bir bakış açısı içerdiğini belirtmiştir. Bu nadir durumun bileşenleri, nedenleri ve ona maruz kalanların kim olduklarını açığa çıkartma amacında olduklarını ve nadir görülen durumların anket yoluyla incelenmesinde başlıca sorunun anlamlı bir örnekleme ulaşabilmek için çok yüksek sayıda haneye anket yapmak zorunluluğu olduğunu vurgulamıştır. \%5 oranında bir katastrofi tespit edebilmek için çok kaba bir hesapla 20.000 anket yapılması, \%1 katastrofi için, yine kaba bir hesapla, 100,000 örneklem gerekliliği örnekleri ile durumun güçlüğünü net bir şekilde ortaya koymuştur.

Böylesi bir örnekleme ulaşma güçlüğünü aşabilmek için iki aşamalı bir anket yöntemi izlediklerini belirten Sayın Erus, ön çalışma ile risk altında olanlar ve olmayanlar için katastrofik harcama yapan hane oranlarını belirlemek ve ilk aşamada risk altında olan haneleri bir tarama anketi ile tespit edeceklerin, ikinci aşamada risk altında olanlardan daha yüksek diğerlerinden daha düşük sayıda haneye asıl anketi, yani cepten yapılan sağlı harcamaları anketini, uygulayacaklarını belirtmiştir. Anketi bir günde yapmanın olanaksızlığını 2-3 aylık bir sürece yayıldığını ve bu sürecin ön çalışma ile üretilen olasılıkların güncellenmesi olanağını verdiğini belirtmiştir.

Tarama ile ayrıştırılması planlanan grupların nesnel ve öznel durumlar olarak ikiye ayrıldığını, nesnel durumların engellilik, yaşlılık, yataklı tedavi görmüş olma ve kronik hastalık olduğunu öznel durumların ise sağlı harcamaları nedeniyle maddi sıkıntı yaşanması ve hane bireylerinin sağlık sorunları nedeniyle iş gücü kaybı yaşaması olduğunu belirtmiştir. Özellikle çok da dikkati çekmeyen ve üzerinde durulmayan bir katastrofik harcama kalemi olan işgücü kaybından ana ankete örneklem çekmenin önemli olacağını belirtmiştir. İkinci aşamaya seçilecek hanelerin önemli bir kısmı tarama sorularına olumlu cevap verenlerden, 2-3 bini ise hiçbir soruya olumlu cevap vermeyenlerden oluşacağını belirterek tarama ile yakalanmama olasılığı bulunan hanelere de bu yolla erişilmeye çalışıldığının altını çizmiştir. 50.000 tarama anketi yapılması durumunda 15.000 haneye detaylı anket yapmak gerekeceğini ve bu durumda 
1000 kadar katastrofik durum yakalama şansı olacağının altını çizmiştir. Çift aşamalı anket yönteminde detaylı anketin daha küçük bir örnekleme uygulanması ile zaman tasarrufu sağlanacağının altını çizmiştir.

Sağlık harcamaları verilerinin toplanması ile ilgili olarak yapılan araştırmalarda iki yöntem kullanıldığını, bunlardan birincisinin, hanelerin bir deftere harcamalarını kaydetmesi olduğunu ve bunun hanehalkı bütçe anketlerinde görüldügüünü, ikinci yöntemin ise harcamaların bir anketör tarafından haneye yöneltilecek sorular ile öğrenilmesi yöntemi olduğunu belirtmiştir. Defter yönteminde bir takım sorunlar olduğu, daha düşük rakamların çıktığının altını çizmiş, özellikle katastrofik harcama durumunda defterin düzgün bir şekilde kaydedilmesinin pek mümkün olmadığını belirtmiştir. Çalışmalarında ikinci yöntemi, 45-50 dakikalık bir anketin bir anketör aracılığıyla uygulanmasını tercih ettiklerini belirtmiştir. 